\title{
Dendrimer-Functionalized Iron Oxide Nanoparticles for Specific Targeting and Imaging of Cancer Cells**
}

\author{
By Su He Wang,* Xiangyang Shi,* Mary Van Antwerp, Zhengyi Cao, Scott D. Swanson, Xiangdong Bi, \\ and James R. Baker, Jr.*
}

We demonstrated a unique approach that combines a layer-by-layer (LbL) self-assembly method with dendrimer chemistry to functionalize $\mathrm{Fe}_{3} \mathrm{O}_{4}$ nanoparticles (NPs) for specific targeting and imaging of cancer cells. In this approach, positively charged $\mathrm{Fe}_{3} \mathrm{O}_{4} \mathrm{NPs}\left(8.4 \mathrm{~nm}\right.$ in diameter) synthesized by controlled co-precipitation of $\mathrm{Fe}^{\mathrm{II}}$ and $\mathrm{Fe}^{\mathrm{III}}$ ions were modified with a bilayer composed of polystyrene sulfonate sodium salt and folic acid (FA)- and fluorescein isothiocyanate (FI)-functionalized poly(amidoamine) dendrimers of generation $5\left(\mathrm{G} 5 . \mathrm{NH}_{2}\right.$-FI-FA) through electrostatic $\mathrm{LbL}$ assembly, followed by an acetylation reaction to neutralize the remaining surface amine groups of G5 dendrimers. Combined flow cytometry, confocal microscopy, transmission electron microscopy, and magnetic resonance imaging studies show that $\mathrm{Fe}_{3} \mathrm{O}_{4} / \mathrm{PSS} / \mathrm{G} 5$.NHAc-FI-FA NPs can specifically target cancer cells overexpressing FA receptors. The present approach to functionalizing $\mathrm{Fe}_{3} \mathrm{O}_{4} \mathrm{NPs}_{\text {opens a new }}$ avenue to fabricating various NPs for numerous biological sensing and therapeutic applications.

\section{Introduction}

Magnetic nanoparticles (NPs) have many interesting biomedical applications. ${ }^{[1-5]}$ They have been used as contrast agents for magnetic resonance (MR) imaging and colloidal mediators for magnetic hyperthermia of cancer. ${ }^{[6]}$ One major issue related to cancer applications of NPs is the lack of specific binding of NPs to cancer cells. In order to achieve the specific targeting of cancer cells, various proteins such as transferrin, ${ }^{[7-10]}$ herceptin, ${ }^{[11,12]}$ and chlorotoxin ${ }^{[13]}$ have been conjugated onto iron oxide NP surfaces. The applied protein ligands display inherent immunogenecity. The specific ligand-receptor or antibody-antigen interaction occurs on the cell membrane, thereby limiting the intracellular uptake of conjugated NPs. ${ }^{[11,12]}$ It is believed that these disadvantages can be overcome by using a small molecular weight ligand linked to iron

[*] Dr. S. H. Wang, Dr. X. Shi, Prof. J. R. Baker, Jr., M. Van Antwerp, Z. Cao, Dr. X. Bi

Michigan Nanotechnology Institute for Medicine and Biological Sciences

University of Michigan

Ann Arbor, MI 48109 (USA)

E-mail:shidasui@umich.edu; xshi@umich.edu; jbakerjr@umich.edu Dr. S. D. Swanson

Department of Radiology, Medical School, University of Michigan Ann Arbor, MI 48109 (USA)

[*-口] S. H.W. and X. S. contributed equally to this work This work has been jointly supported by the National Institutes of Health $(\mathrm{NIH})$ (NIH 1 ROI EB002657), and National Cancer Institute (NCI), National Institutes of Health (NIH) (NOI-CO-97111 and NIH 1 R01 CA119409). We thank Sasha Meshinchi for his assistance with the TEM experiments and valuable discussions, and Roger A. Pinto for his help with atomic absorption spectroscopy measurements. Supporting Information is available online from Wiley InterScience or from the authors. oxide NPs. Several groups have investigated the conjugation of folic acid (FA) onto iron oxide NPs for targeting cancer cells. $^{[14-16]}$ The conjugation methods employed have involved complicated multi-step synthesis and modification procedures. In most cases, this has made it difficult to simultaneously couple other molecules onto iron oxide NP surfaces to achieve multifunctionalities. Therefore, the fabrication of targeted iron oxide NPs that also have conjugated drug or imaging molecules remains a challenge.

One approach relevant to NP surface modifications is the electrostatic layer-by-layer self-assembly technique ${ }^{[17-19]}$ that allows the creation of ultra-thin functional films on NP surfaces. ${ }^{[20-24]}$ The biofunctionality of the NPs is able to be tuned by deposition of functional polyelectrolytes or biomacromolecules on the NP surfaces. ${ }^{[25,26]}$ For example, Wang et al constructed CdTe quantum dot/polyelectrolyte (PE) multilayers onto polystyrene microparticles, followed by an assembly of an outermost layer of anti-immunoglobulin for subsequent immunosensing. ${ }^{[25]}$ Caruso and co-workers demonstrated that the biotin-functionalized $\mathrm{Au} \mathrm{NP/polyelectrolyte-coated} \mathrm{latexes} \mathrm{ter-}$ minated by FI-anti-biotin IgG can be used for homogeneous, competitive fluorescence quenching immunoassay of biotin molecules. ${ }^{[26]}$ In another recent work of the same group, it is shown that multilayered sub-micrometer sized polystyrene particles modified with a humanized A33 monoclonal antibody can specifically target A33 antigen-expressing LIM1215 colorectal cancer cells. ${ }^{[27]}$

Recent advances in dendrimer chemistry show that poly(amidoamine) (PAMAM) dendrimers can be covalently linked with defined numbers of targeting ligands, imaging dyes, and drugs, thus providing a platform for the specific targeting, imaging, and treatment of cancer. ${ }^{[28-32]}$ We here attempt to combine the unique features of dendrimer chemistry with the versatile, LbL self-assembly technique that provides a facile 
approach to fabricating multifunctional iron oxide NPs for targeting and imaging of cancer cells. To accomplish this, we assembled iron oxide NPs with a polyelectrolyte (polystyrene sulfonate sodium salt, PSS) and a generation 5 PAMAM dendrimer prefunctionalized with FA and fluorescein isothiocyanate (FI) moieties (G5. $\mathrm{NH}_{2}$-FI-FA) on the surface of iron oxide NPs using the LbL self-assembly technique. The PSS/G5. $\mathrm{NH}_{2}$-FI-FA bilayer-coated iron oxide NPs were then subjected to an acetylation reaction to neutralize the remaining terminal amine groups of the dendrimers (Fig. 1). The formed FI- and FA-functionalized iron oxide NPs display very high specific binding affinity to cancer cells overexpressing FA receptors (FAR), as demonstrated by flow cytometry, confocal microscopy, transmission electron microscopy (TEM), and MR imaging. To our knowledge, this is the first example of the fabrication of multifunctional iron oxide NPs by combining the LbL self-assembly technique with dendrimer chemistry.

\section{Results and Discussion}

\subsection{Characterization of Functionalized Iron Oxide Nanoparticles}

The magnetic iron oxide $\left(\mathrm{Fe}_{3} \mathrm{O}_{4}\right)$ NPs were synthesized by controlled co-precipitation of $\mathrm{Fe}^{\mathrm{II}}$ and $\mathrm{Fe}{ }^{\mathrm{III}}$ ions according to the literature. ${ }^{[33]}$ The synthesized $\mathrm{Fe}_{3} \mathrm{O}_{4}$ NPs $(8.4 \pm 1.4 \mathrm{~nm}$ in diameter as verified by TEM) are positively charged (zeta potential $=+42.02 \mathrm{mV}$ ), which allows the subsequent self-assembly of a negatively charged PSS polyelectrolyte followed by a positively charged G5. $\mathrm{NH}_{2}$-FI-FA or G5. $\mathrm{NH}_{2}$-FI dendrimer. The $\mathrm{Fe}_{3} \mathrm{O}_{4} / \mathrm{PSS} / \mathrm{G} 5 . \mathrm{NH}_{2}$-FI-FA or $\mathrm{Fe}_{3} \mathrm{O}_{4} / \mathrm{PSS} / \mathrm{G} 5 . \mathrm{NH}_{2}$-FI NPs formed were subjected to an acetylation reaction to neutralize the remaining terminal amine groups of the dendrimers (Fig. 1). Zeta potential measurements were used to monitor each step of the coating and functionalization of $\mathrm{Fe}_{3} \mathrm{O}_{4} \mathrm{NPs}$ (Table 1). The alternating charge reversal of $\mathrm{Fe}_{3} \mathrm{O}_{4}$ NPs after coating with PSS and G5. $\mathrm{NH}_{2}$-FI or G5. $\mathrm{NH}_{2}$-FI-FA dendrimers indicates the successful electrostatic assembly. After the acetylation reaction, the zeta potentials of both $\mathrm{Fe}_{3} \mathrm{O}_{4} / \mathrm{PSS} /$

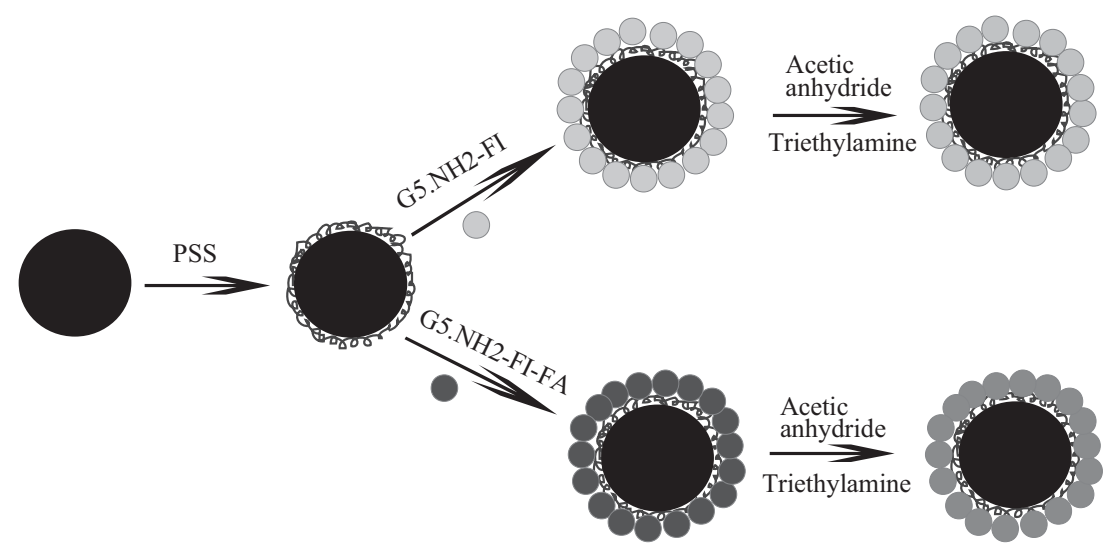

Figure 1. Schematic representation of the fabrication of targeted iron oxide NPs.
Table 1. Zeta potential values of $\mathrm{Fe}_{3} \mathrm{O}_{4} \mathrm{NPs}$ after each step modification.

\begin{tabular}{lc}
\hline Nanoparticles & Zeta potential $[\mathrm{mV}]$ \\
\hline $\mathrm{Fe}_{3} \mathrm{O}_{4}$ & +42.02 \\
$\mathrm{Fe}_{3} \mathrm{O}_{4} / \mathrm{PSS}$ & -45.04 \\
$\mathrm{Fe}_{3} \mathrm{O}_{4} / \mathrm{PSS} / \mathrm{C} 5 . \mathrm{NH}_{2}$ - $\mathrm{Fl}$ & +52.81 \\
$\mathrm{Fe}_{3} \mathrm{O}_{4} / \mathrm{PSS} / \mathrm{C5} . \mathrm{NH}_{2}$ - $\mathrm{Fl}-\mathrm{FA}$ & +43.08 \\
$\mathrm{Fe}_{3} \mathrm{O}_{4} / \mathrm{PSS} / \mathrm{C} 5 . \mathrm{NHAc}-\mathrm{FI}$ & +31.48 \\
$\mathrm{Fe}_{3} \mathrm{O}_{4} / \mathrm{PSS} / \mathrm{G} 5 . \mathrm{NHAc}-\mathrm{FI}-\mathrm{FA}$ & +23.86 \\
\hline
\end{tabular}

G5.NHAc-FI and $\mathrm{Fe}_{3} \mathrm{O}_{4} / \mathrm{PSS} / \mathrm{G}$ 5.NHAc-FI-FA significantly decreased due to the conversion of the dendrimer surface amine groups to acetamide groups. It is interesting to note that the zeta potentials of neither $\mathrm{Fe}_{3} \mathrm{O}_{4} / \mathrm{PSS} / \mathrm{G} 5$.NHAc-FI nor $\mathrm{Fe}_{3} \mathrm{O}_{4} / \mathrm{PSS} / \mathrm{G} 5$. NHAc-FI-FA NPs are close to zero. This implies that some of the dendrimer terminal amines that interact with PSS polymer chains due to electrostatic interaction cannot be acetylated. We believe that the few remaining positive charges of $\mathrm{Fe}_{3} \mathrm{O}_{4}$ NPs would not cause significant non-specific binding with tumor cells, because the outermost surface amines of dendrimer layer are acetylated. The functionalized $\mathrm{Fe}_{3} \mathrm{O}_{4}$ NPs with the bilayer coating and acetylation reaction are colloidally stable in aqueous solution as well as in cell culture medium for at least 6 months at concentrations up to $10 \mathrm{mg} \mathrm{mL}^{-1}$. The selection of the bilayer coating in this study is to demonstrate a concept that the LbL assembly combined with dendrimer chemistry can be used to functionalize preformed NPs. We also think that several layers' coating with the outermost dendrimer layer may be applicable for improving the mechanical stability of the particles for in vivo studies. However, more layers' coating may increase the risk of weakening the colloidal stability of the particles. It is worthwhile to note that the approach combining the LbL assembly method with dendrimer chemistry is essential to make the iron oxide NPs functional biologically. It is known that carboxyl-terminated PAMAM dendrimers can be self-assembled onto iron oxide nanoparticle surfaces. ${ }^{[34,35]}$ Our unpublished data show that iron oxide NPs directly modified with carboxyl acid-terminated dendrimers functionalized with FA moieties through electrostatic interaction do not specifically bind $\mathrm{KB}$ cells overexpressing FA receptors, presumably due to the carboxyl groups on the dendrimer surface. Fabrication of iron oxide NPs with neutral or close to neutral surface charge is essential to facilitate the specific binding through receptor-mediated endocytosis.

The self-assembled bilayers of PSS/ G5.NHAc-FI and PSS/G5.NHAc-FI-FA on $\mathrm{Fe}_{3} \mathrm{O}_{4}$ NPs were also characterized by TEM imaging. The TEM image of PSS/G5.NHAcFI-FA-coated $\mathrm{Fe}_{3} \mathrm{O}_{4}$ NPs (Fig. 2a) shows that, after the bilayer self-assembly and chemical functionalization, the particles display similar morphology to the ones before self-assembly (Fig. S4, Supporting Information). The aggregated nanoparticles shown in the TEM image 


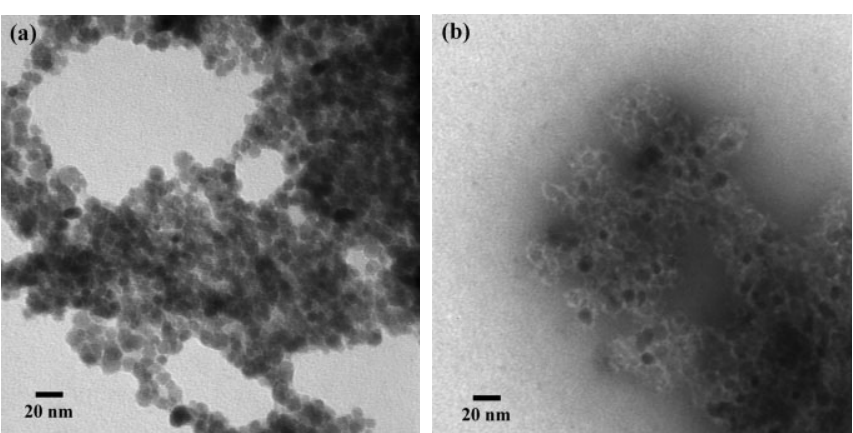

Figure 2. TEM images of the PSS/G5.NHAc-FI-FA-coated $\mathrm{Fe}_{3} \mathrm{O}_{4} \mathrm{NPs}$. a) Image without staining; and b) image with phosphotungstic acid negative staining.

(Fig. 2) only reflected the dry state of the particles deposited onto carbon-coated copper grid before TEM experiment, which is consistent with literature data. ${ }^{[3]}$ The TEM data do not necessarily verify that the particles aggregate in aqueous solution. As mentioned above, the functionalized $\mathrm{Fe}_{3} \mathrm{O}_{4} \mathrm{NPs}$ are stable in both aqueous solution and cell culture medium. A negatively stained (phosphotungstic acid) TEM image (Fig. 2b) clearly shows that all $\mathrm{Fe}_{3} \mathrm{O}_{4} \mathrm{NPs}$ are surrounded with the bright rings of the polymer bilayers of PSS/G5.NHAc-FI-FA, further confirming the successful self-assembly process. PSS/ G5.NHAc-FI-coated $\mathrm{Fe}_{3} \mathrm{O}_{4}$ NPs display similar polymer ring structures to those of PSS/G5.NHAc-FI-FA-coated $\mathrm{Fe}_{3} \mathrm{O}_{4}$ NPs as observed from the negatively stained TEM images (data not shown).

\subsection{Cytotoxicity Assay}

The cytotoxicity of the functionalized $\mathrm{Fe}_{3} \mathrm{O}_{4}$ NPs was evaluated by fluorescein diacetate (FDA) and propidium iodide (PI) staining and by observing cell morphology changes after incubation with the $\mathrm{Fe}_{3} \mathrm{O}_{4}$ NPs for 96 h. Cell viability data (Fig. S5, Supporting Information) show that the $\mathrm{KB}$ cells (a human epithelial carcinoma cell line) treated by functionalized $\mathrm{Fe}_{3} \mathrm{O}_{4}$ NPs with or without FA conjugation display similar percentage of FDA positive cells to the KB cells treated by unmodified $\mathrm{Fe}_{3} \mathrm{O}_{4} \mathrm{NPs}$ at an $\mathrm{Fe}$ concentration of $0-150 \mu \mathrm{g} \mathrm{mL}^{-1}$. Phase contrast microscopy images show that even at an Fe concentration of up to $150 \mu \mathrm{g} \mathrm{mL}^{-1}, \mathrm{~KB}$ cells treated with either $\mathrm{Fe}_{3} \mathrm{O}_{4} /$ PSS/G5.NHAc-FI or $\mathrm{Fe}_{3} \mathrm{O}_{4} / \mathrm{PSS} / \mathrm{G} 5$.NHAc-FI-FA NPs display the same morphology as those treated with PBS buffer (Fig. S6, Supporting Information), indicating that the PSS/dendrimer bilayer functionalized $\mathrm{Fe}_{3} \mathrm{O}_{4} \mathrm{NPs}$ are biocompatible at an Fe concentration of up to $150 \mu \mathrm{g} \mathrm{mL}^{-1}$.

\subsection{Flow Cytometry}

The FA and the dye FI modified onto the G5 dendrimer surface were used as a targeting ligand and an imaging molecule, respectively. This affords the functionalized $\mathrm{Fe}_{3} \mathrm{O}_{4} \mathrm{NPs}$ with both targeting and imaging functionalities. Folic acid receptor (FAR) is well known to be overexpressed in several human car- cinomas including breast, ovary, endometrium, kidney, lung, head and neck, brain, and myeloid cancers. ${ }^{[36-38]}$ In this study, $\mathrm{KB}$ cells expressing both high- and low-levels of FAR (denoted as KB-HFAR and KB-LFAR, respectively) were selected for the intracellular uptake of functionalized $\mathrm{Fe}_{3} \mathrm{O}_{4}$ NPs. Figure 3 illustrates the binding of PSS/G5.NHAc-FI-FA- and PSS/G5.NHAc-FI-coated $\mathrm{Fe}_{3} \mathrm{O}_{4} \quad \mathrm{NPs} \quad(\mathrm{Fe}$ concentration $=4.5 \mu \mathrm{g} \mathrm{mL}^{-1}$ ) in KB-HFAR and KB-LFAR cells investigated by flow cytometry. It is clear that after binding of PSS/G5.NHAc-FI-FA-coated $\mathrm{Fe}_{3} \mathrm{O}_{4}$ NPs with KB-HFAR cells, the fluorescence signal significantly increases (Fig. 3a). In contrast, PSS/G5.NHAc-FI-modified $\mathrm{Fe}_{3} \mathrm{O}_{4}$ NPs without FA conjugation display a similar fluorescence signal to the PBS control, suggesting no measurable binding to KB-HFAR cells. For KB-LFAR cells, neither $\mathrm{Fe}_{3} \mathrm{O}_{4} / \mathrm{PSS} / \mathrm{G} 5$.NHAc-FI nor $\mathrm{Fe}_{3} \mathrm{O}_{4} / \mathrm{PSS} / \mathrm{G} 5$.NHAc-FI-FA NPs display significant binding (Fig. 3b). This indicates that the binding of the FA-modified $\mathrm{Fe}_{3} \mathrm{O}_{4}$ NPs to $\mathrm{KB}$ cells is mediated by the FAR. We also investigated the dose-dependent cellular uptake of the functionalized $\mathrm{Fe}_{3} \mathrm{O}_{4}$ NPs (Fig. 3c and d). At an Fe concentration above $2.3 \mu \mathrm{g} \mathrm{mL}^{-1}$, KB-HFAR cells exposed to $\mathrm{Fe}_{3} \mathrm{O}_{4} / \mathrm{PSS} /$ G5.NHAc-FI-FA NPs show remarkably higher fluorescence signals than those treated with $\mathrm{Fe}_{3} \mathrm{O}_{4} / \mathrm{PSS} / \mathrm{G} 5$.NHAc-FI NPs without FA (Fig. 3c). This again implies that the high affinity of FAR mediates specific uptake of the NPs.

Both $\mathrm{Fe}_{3} \mathrm{O}_{4} / \mathrm{PSS} / \mathrm{G} 5 . \mathrm{NHAc}-\mathrm{FI}$ and $\mathrm{Fe}_{3} \mathrm{O}_{4} / \mathrm{PSS} / \mathrm{G} 5 . \mathrm{NHAc}$-FIFA NPs display much less uptake in KB-LFAR cells than in KB-HFAR cells, even at an $\mathrm{Fe}$ concentration of up to $90 \mu \mathrm{g} \mathrm{mL}^{-1}$ (Fig. 3d). However, in the studied concentration range, $\mathrm{Fe}_{3} \mathrm{O}_{4}$ NPs with FA conjugation exhibit more uptake in KB-LFAR cells than those without FA modification, which is quite different than that of single FA-modified G5 dendrimers. ${ }^{[30]}$ It implies that the FA-modified $\mathrm{Fe}_{3} \mathrm{O}_{4}$ NPs display higher binding sensitivity than that of FA-modified G5 dendrimers. The higher binding capacity of FA-modified $\mathrm{Fe}_{3} \mathrm{O}_{4} \mathrm{NPs}$ may stem from the polyvalency effect due to multiple FA ligands presented onto each $\mathrm{Fe}_{3} \mathrm{O}_{4}$ NP surface. ${ }^{[39,40]}$ The number of FA ligands $(n)$ per $\mathrm{Fe}_{3} \mathrm{O}_{4} \mathrm{NP}$ can be calculated according to the following equation:

$n=n_{1} \times \frac{4 \pi r_{1}^{2}}{\pi r_{2}^{2}}$

where $r_{1}$ and $r_{2}$ are the radius of PSS-modified $\mathrm{Fe}_{3} \mathrm{O}_{4}$ NPs and G5.NHAc-FI-FA dendrimers, respectively, and $n_{1}$ is the number of FA moieties per G5 dendrimer. Note that the calculation is based on the following assumptions: (1) a densely packed monolayer of G5.NHAc-FI-FA dendrimer is presented onto the $\mathrm{Fe}_{3} \mathrm{O}_{4}$ NP surfaces; (2) each dendrimer molecule shows a pancake shape when deposited onto the $\mathrm{Fe}_{3} \mathrm{O}_{4} \mathrm{NP}$ surfaces ${ }^{[41,42]}$ and the diameter of the pancake shape does not change significantly, compared with that of dendrimers in solution; (3) the PSS polymer layer thickness is $2 \mathrm{~nm} ; ;^{[43]}$ and (4) there are half the number of FA (2.4) moieties presented in each dendrimer molecule available for binding (based on the geometry of dendrimer shape and stochastic distribution of FA moieties onto each G5.NHAc-FI-FA dendrimer). The number 

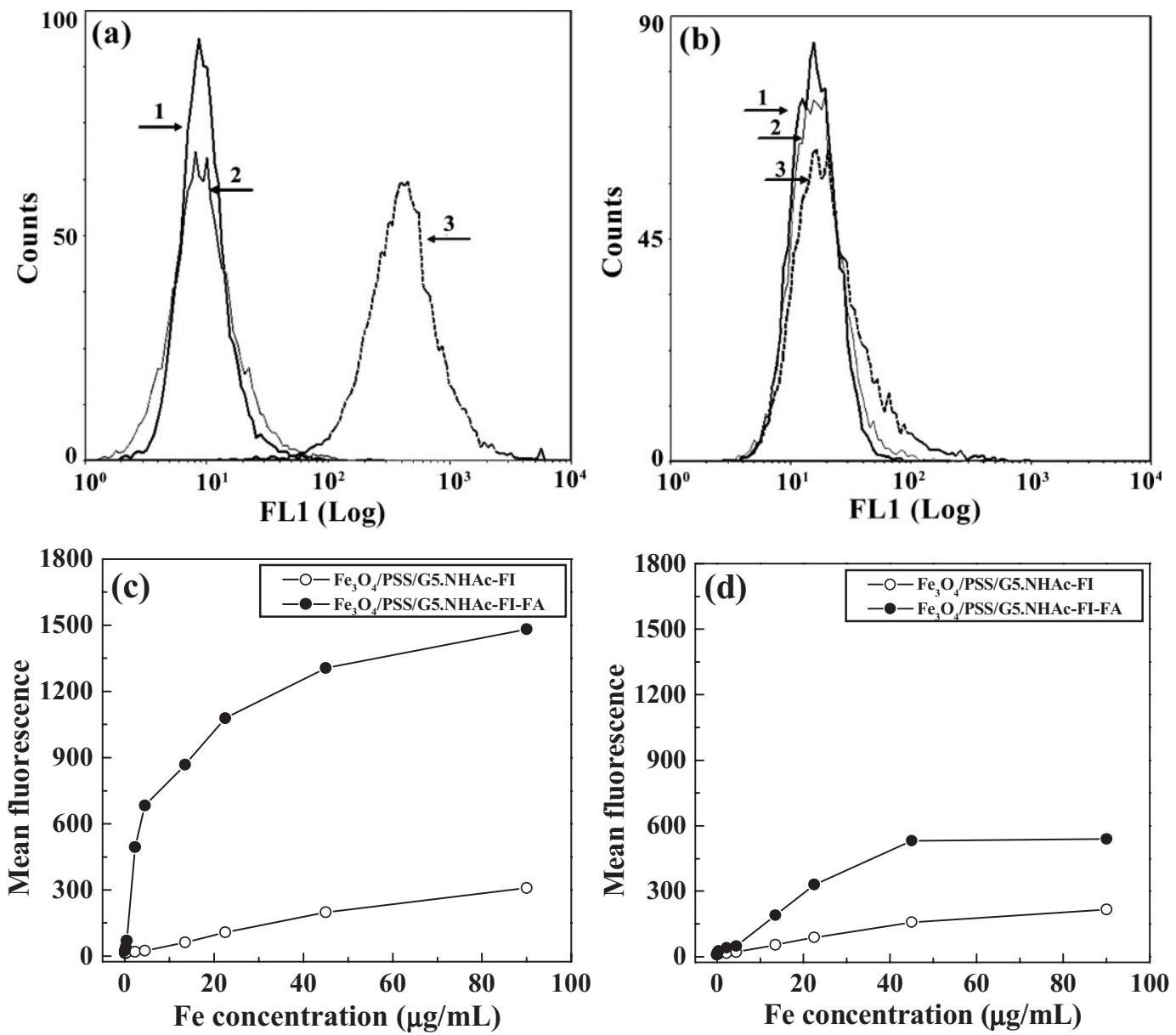

Figure 3. Binding of $\mathrm{Fe}_{3} \mathrm{O}_{4} \mathrm{NPs}$ modified with PSS/G5.NHAc-FI and PSS/G5.NHAc-FI-FA bilayers with KB cells. a) KB cells expressing high-level FAR; and b) KB cells with low-level FAR. 1. PBS control (black line); 2. PSS/G5.NHAc-Fl-modifed $\mathrm{Fe}_{3} \mathrm{O}_{4} \mathrm{NPs}$ (grey line); 3. PSS/G5.NHAc-FI-FA-modifed $\mathrm{Fe}_{3} \mathrm{O}_{4} \mathrm{NPs}$ (dotted line). FL1 indicates the green fluorescence signal intensity generated from $\mathrm{FI}$. Dose-dependent binding of functionalized $\mathrm{Fe}_{3} \mathrm{O}_{4} \mathrm{NPs}_{\mathrm{s}}$ with KB cells expressing high- $c$ ) and low- d) level FAR.

of FA moieties per $\mathrm{Fe}_{3} \mathrm{O}_{4} \mathrm{NPs}$ was calculated to be $\sim 35.6$, using the average diameter of PSS-coated $\mathrm{Fe}_{3} \mathrm{O}_{4}$ NPs $(10.4 \mathrm{~nm})$ and $\mathrm{G} 5$ dendrimers $(5.4 \mathrm{~nm}) .{ }^{[44]}$ The larger number of FA moieties per $\mathrm{Fe}_{3} \mathrm{O}_{4} \mathrm{NP}$ compared with single FA-modified dendrimer (4.8 FA per dendrimer) facilitates the polyvalency effect, thereby significantly increasing the binding affinity of $\mathrm{Fe}_{3} \mathrm{O}_{4} \mathrm{NPs}$ on each $\mathrm{KB}$ cell. It should be noted that in the in vitro binding experiment, the use of KB-LFAR cells conveys similar information to the free-FA blocking experiment performed with dendrimer nanodevices in our group. ${ }^{[30,45]}$

\subsection{Confocal Microscopy Observations}

The self-assembly of G5.NHAc-FI-FA dendrimers onto $\mathrm{Fe}_{3} \mathrm{O}_{4}$ NPs also affords the utilization of confocal microscopic imaging of the intracellular uptake of $\mathrm{Fe}_{3} \mathrm{O}_{4} \mathrm{NPs}$. It is clear that after treatment with $\mathrm{Fe}_{3} \mathrm{O}_{4} / \mathrm{PSS} / \mathrm{G} 5 . \mathrm{NHAc}-\mathrm{FI}-\mathrm{FA}$ NPs for $2 \mathrm{~h}$, the green FI fluorescence signals appear in the cytosol of KB-HFAR cells (Fig. 4c). In contrast, KB-HFAR cells treated with $\mathrm{Fe}_{3} \mathrm{O}_{4}$ /PSS/G5.NHAc-FI without FA conjugation do not show a FI fluorescence signal, similar to the KB-HFAR cells treated with PBS buffer (Fig. 4a and b). The confocal imaging data suggest that the intracellular uptake of $\mathrm{Fe}_{3} \mathrm{O}_{4} / \mathrm{PSS} /$ G5.NHAc-FI-FA NPs into KB-HFAR cells is through the FAR-mediated endocytosis.

\subsection{Transmission Electron Microscopy (TEM) Imaging}

The specific intracellular uptake of FA-modified $\mathrm{Fe}_{3} \mathrm{O}_{4} \mathrm{NPs}$ was further verified by TEM. The TEM imaging technique allows for clear identification of the $\mathrm{Fe}_{3} \mathrm{O}_{4} \mathrm{NPs}$ in different cellular entities. TEM images of KB-HFAR cells treated with $\mathrm{Fe}_{3} \mathrm{O}_{4} / \mathrm{PSS} / \mathrm{G} 5 . \mathrm{NHAc}-\mathrm{FI}-\mathrm{FA}$ NPs for $2 \mathrm{~h}$ show that the NPs distributed predominantly into the vacuoles of the cells (Fig. 5a and $b$ ), whereas the lyosomes and the nucleus do not show any uptake of $\mathrm{Fe}_{3} \mathrm{O}_{4} / \mathrm{PSS} / \mathrm{G}$ 5.NHAc-FI-FA NPs. In contrast, we did not observe any significant uptake of $\mathrm{Fe}_{3} \mathrm{O}_{4} / \mathrm{PSS} /$ G5.NHAc-FI NPs without FA modification (Fig. 5c). There was only minimal uptake of $\mathrm{Fe}_{3} \mathrm{O}_{4} / \mathrm{PSS} / \mathrm{G} 5$.NHAc-FI NPs randomly distributed in the vacuoles of some cells (Fig. S7, Supporting Information), which was undetectable using confocal microscopy. This minimal uptake might be related to diffusion- 

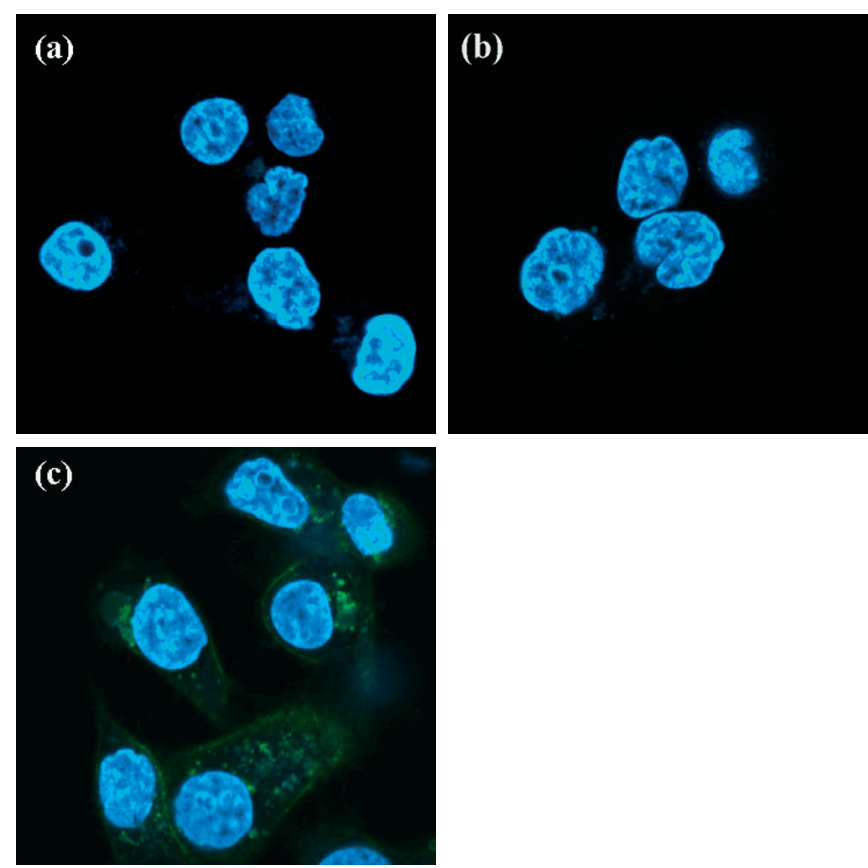

Figure 4. Confocal microscopy images of KB-HFAR cells with different treatments for $2 \mathrm{~h}$. a) KB cells treated with PBS buffer; b) KB cells treated with $\mathrm{Fe}_{3} \mathrm{O}_{4} / \mathrm{PSS} / \mathrm{G} 5$. NHAc-FI NPs; and c) $\mathrm{KB}$ cells treated with $\mathrm{Fe}_{3} \mathrm{O}_{4} /$ PSS/G5.NHAc-FI-FA NPs. The nucleus of cells was blue-stained with Hoescht33342. The green color was originated from the FI dye conjugated on dendrimers.
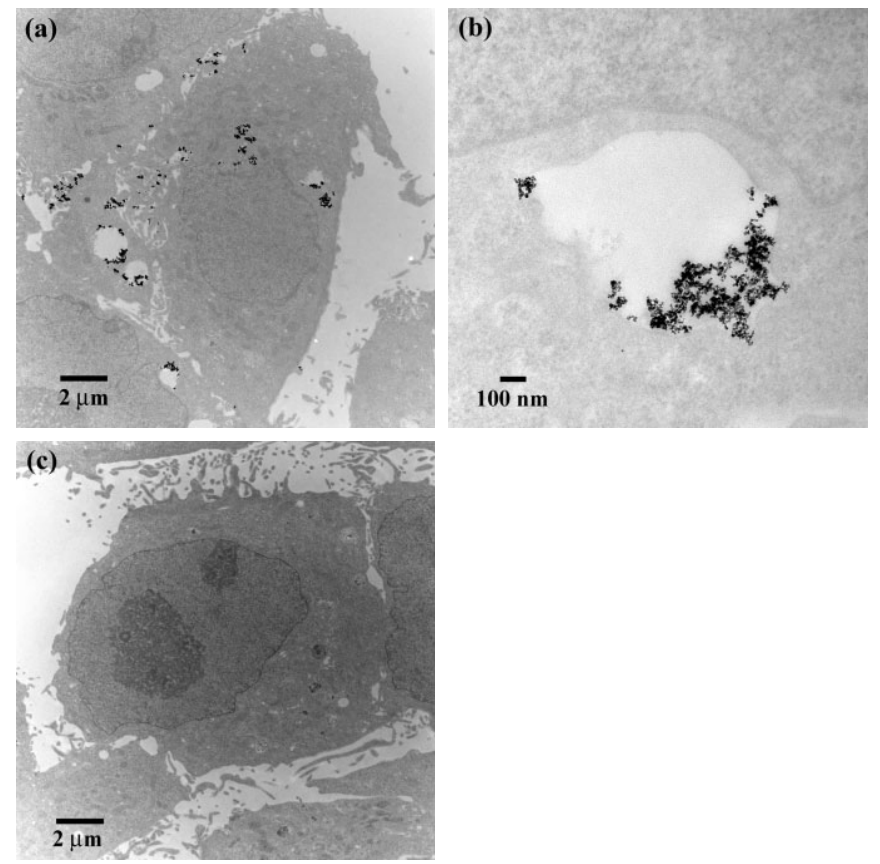

Figure 5. TEM images of KB-HFAR cells treated with NPs for $2 \mathrm{~h}$. a) and b) $\mathrm{KB}$ cells treated with $\mathrm{Fe}_{3} \mathrm{O}_{4} / \mathrm{PSS} / \mathrm{G} 5 . \mathrm{NHAc}$-FI-FA NPs; c) KB cells treated with $\mathrm{Fe}_{3} \mathrm{O}_{4} / \mathrm{PSS} / \mathrm{G}$.NHAc-FI NPs. b) shows a magnified area of a typical vacuolar structure of a KB-HFAR cell. driven non-specific binding since control cells without treatment of $\mathrm{Fe}_{3} \mathrm{O}_{4}$ NPs did not show any internalized NPs. The TEM studies underline the high specificity of FA-modified $\mathrm{Fe}_{3} \mathrm{O}_{4}$ NPs for targeting KB-HFAR cells, in agreement with the confocal imaging data.

\subsection{Magnetic Resonance (MR) Imaging}

MR imaging is often used for the diagnosis and staging of cancer. Iron oxide NPs affect the MR signal by dephasing transverse magnetization and hence reducing the value of $\mathrm{T} 2$. A targeted iron oxide NP would have a major benefit in cancer imaging by specifically detecting tumors that over-express the FAR. To study the effect of $\mathrm{Fe}_{3} \mathrm{O}_{4} / \mathrm{PSS} / \mathrm{G} 5$.NHAc-FI-FA NPs on cancer cells, we measured the T2 of KB-HFAR cells exposed to differing concentrations of $\mathrm{Fe}_{3} \mathrm{O}_{4} / \mathrm{PSS} / \mathrm{G} 5$.NHAc-FIFA NPs. The T2 values of KB-HFAR cell pellets treated with $\mathrm{Fe}_{3} \mathrm{O}_{4} / \mathrm{PSS} / \mathrm{G} 5 . \mathrm{NHAc}-\mathrm{FI}-\mathrm{FA}$ NPs dramatically decreased as a function of $\mathrm{Fe}$ concentration (Table 2). In contrast, the decreasing trend of $\mathrm{T} 2$ values as a function of $\mathrm{Fe}$ concentration for the same $\mathrm{KB}$ cells treated with $\mathrm{Fe}_{3} \mathrm{O}_{4} / \mathrm{PSS} / \mathrm{G} 5 . \mathrm{NHAc}-\mathrm{FI}$

Table 2. MR signals of KB-HFAR cells treated with functionalized $\mathrm{Fe}_{3} \mathrm{O}_{4}$ NPs.

\begin{tabular}{lcccc}
\hline Fe Concentration & \multicolumn{2}{c}{$\mathrm{Tl}[\mathrm{s}]$} & \multicolumn{2}{c}{$\mathrm{T} 2[\mathrm{~s}]$} \\
{$[\mu \mathrm{gg} / \mathrm{mL}]$} & $\mathrm{Fe}_{3} \mathrm{O}_{4}-\mathrm{Fl}[\mathrm{a}]$ & $\mathrm{Fe}_{3} \mathrm{O}_{4}-\mathrm{Fl}-\mathrm{FA}[\mathrm{b}]$ & $\mathrm{Fe}_{3} \mathrm{O}_{4}-\mathrm{Fl}[\mathrm{a}]$ & $\mathrm{Fe}_{3} \mathrm{O}_{4}-\mathrm{Fl}-\mathrm{FA}[\mathrm{b}]$ \\
\hline $0[\mathrm{c}]$ & $2.01 \pm 0.07$ & $2.01 \pm 0.07$ & $0.921 \pm 0.05$ & $0.921 \pm 0.05$ \\
11.3 & $2.24 \pm 0.07$ & $1.58 \pm 0.02$ & $0.357 \pm 0.002$ & $0.332 \pm 0.04$ \\
22.5 & $2.26 \pm 0.03$ & $1.66 \pm 0.04$ & $0.230 \pm 0.008$ & $0.106 \pm 0.004$ \\
45 & $2.46 \pm 0.07$ & $1.23 \pm 0.016$ & $0.12 \pm 0.005$ & $0.042 \pm 0.007$ \\
\hline
\end{tabular}

[a] Denotes $\mathrm{Fe}_{3} \mathrm{O}_{4} /$ PSS/G5.NHAc-FI NPs.

[b] Denotes $\mathrm{Fe}_{3} \mathrm{O}_{4} / \mathrm{PSS} / \mathrm{G} 5 . \mathrm{NHAc}-\mathrm{FI}$-FA NPs.

[c] PBS buffer.

NPs is significantly less than $\mathrm{Fe}_{3} \mathrm{O}_{4} / \mathrm{PSS} / \mathrm{G} 5$.NHAc-FI-FA NPs. In the T2-weighted spin-echo MR images (the color change from red to purple indicates the gradual decrease of MR signal intensity, which is similar to those reported based on the intensity of black color. ${ }^{[11,12]}$ ) obtained using an Fe concentration of $11.3 \mu \mathrm{g} \mathrm{mL}^{-1}, \mathrm{Fe}_{3} \mathrm{O}_{4} / \mathrm{PSS} / \mathrm{G} 5$.NHAc-FI-FA NPs reduces the signal intensity to $50 \%$ of the initial value (PBS control) whereas $\mathrm{Fe}_{3} \mathrm{O}_{4} / \mathrm{PSS} / \mathrm{G}$ 5.NHAc-FI NPs reduces the signal to about $89 \%$ of the initial value (Fig. 6a). This suggested that $\mathrm{Fe}_{3} \mathrm{O}_{4} / \mathrm{PSS} / \mathrm{G}$ 5.NHAc-FI-FA NPs can specifically hamper the MR signal through FAR-mediated binding and endocytosis. At higher Fe concentrations (e.g., $45 \mu \mathrm{g} \mathrm{mL}^{-1}$ ), non-specific binding of $\mathrm{Fe}_{3} \mathrm{O}_{4} / \mathrm{PSS} / \mathrm{G} 5$.NHAc-FI NPs without FA conjugation occurred with KB-HFAR cells. The dose-dependent quantitative MR signal intensity shown in Figure 6b shows a significant MR signal intensity decrease with the increase of Fe concentration for KB-HFAR cells incubated with $\mathrm{Fe}_{3} \mathrm{O}_{4} / \mathrm{PSS} / \mathrm{G} 5 . \mathrm{NHAc}-$ FI-FA NPs. The non-specific uptake of $\mathrm{Fe}_{3} \mathrm{O}_{4} / \mathrm{PSS} / \mathrm{G} 5$.NHAcFI NPs at higher Fe concentrations can also be inferred from 

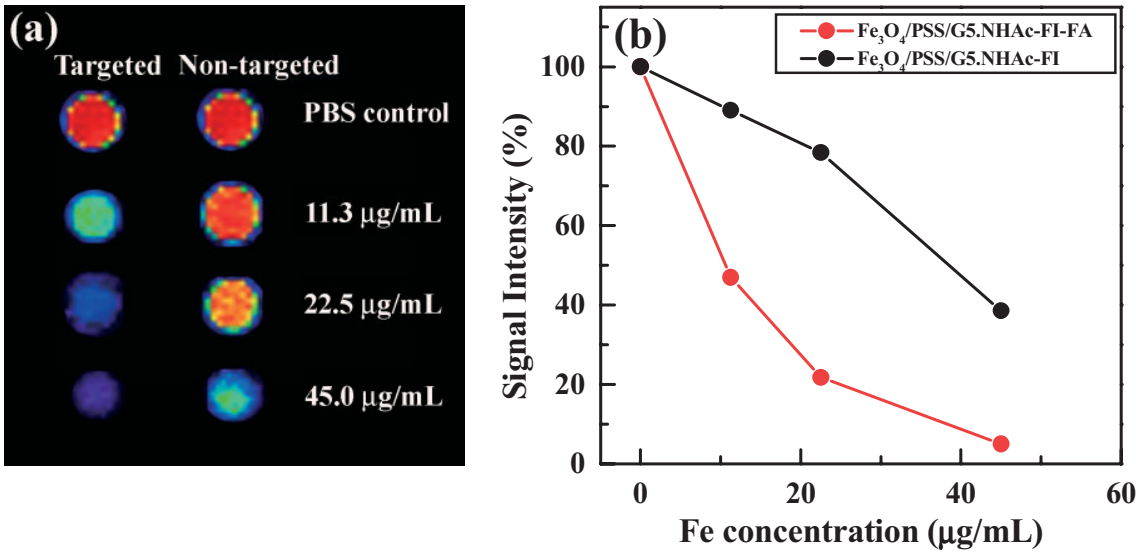

Figure 6. MR imaging of KB-HFAR cell pellets incubated with functionalized $\mathrm{Fe}_{3} \mathrm{O}_{4}$ NPs. a) T2 weighted spin-echo images of cells incubated with functionalized $\mathrm{Fe}_{3} \mathrm{O}_{4} \mathrm{NPs}$ with Fe concentrations of $0,11.3,22.5,45 \mu \mathrm{g} \mathrm{mL} L^{-1}$. Left column, targeted denotes $\mathrm{Fe}_{3} \mathrm{O}_{4} / \mathrm{PSS} / \mathrm{G} 5$.NHAc-FI-FA NPs. Right column, non-targeted denotes $\mathrm{Fe}_{3} \mathrm{O}_{4} / \mathrm{PSS} / \mathrm{G} 5$. NHAc-FI NPs. The color change from red to purple indicates the gradual decrease of MR signal intensity. b) The percentage of signal intensity compared to the cells in PBS was plotted as a function of the Fe concentration for both $\mathrm{Fe}_{3} \mathrm{O}_{4}$ l PSS/G5.NHAc-FI-FA and $\mathrm{Fe}_{3} \mathrm{O}_{4} / \mathrm{PSS} / \mathrm{G} 5 . \mathrm{NHAc}-\mathrm{FI} \mathrm{NPs}$.

Figure $6 \mathrm{~b}$. Thus, lower concentrations of the $\mathrm{Fe}_{3} \mathrm{O}_{4}$ nanoparticles provided better discrimination of KB-HFAR cells.

\section{Conclusions}

In summary, flow cytometry, confocal microscopy, TEM, and MR imaging studies all demonstrated that $\mathrm{Fe}_{3} \mathrm{O}_{4} / \mathrm{PSS} /$ G5.NHAc-FI-FA NPs specifically bind to KB-HFAR cells. In contrast, $\mathrm{Fe}_{3} \mathrm{O}_{4} / \mathrm{PSS} / \mathrm{G}$ 5.NHAc-FI NPs that lack surface FA moieties did not display binding to the KB cells, suggesting that the binding was mediated by the FAR. The approach to functionalizing $\mathrm{Fe}_{3} \mathrm{O}_{4}$ NPs using LbL self-assembly and dendrimer chemistry may be applicable for various NPs and targeting ligands (e.g., sugars, peptides, hormones and the like), thereby providing a general strategy to fabricating various NPs for a range of biological sensing and therapeutics applications. For in vivo applications, the stability of the fabricated $\mathrm{Fe}_{3} \mathrm{O}_{4} \mathrm{NPs}$ may need to be further improved by increasing the polymer layer thickness, which can be achieved by increasing the number of polymer layers via the LbL self-assembly technique. In addition, the mechanical stability of the polymer coating may also need to be improved through shell cross-linking. These experiments and improvements are currently being developed in our lab, and should provide a truly unique approach to functionalized NPs.

\section{Experimental}

Materials: Ethylenediamine core amine-terminated PAMAM dendrimers of generation $5\left(\mathrm{G} 5 . \mathrm{NH}_{2}\right)$ with a polydispersity index less than 1.08 were purchased from Dendritech (Midland, MI). FA, FI, Ferric chloride hexahydrate $\left(\mathrm{FeCl}_{3} \cdot 6 \mathrm{H}_{2} \mathrm{O}>99 \%\right)$, ferrous chloride tetrahydrate $\left(\mathrm{FeCl}_{2} \cdot 4 \mathrm{H}_{2} \mathrm{O}>99 \%\right)$, sodium hydroxide, hydrochloric acid, and all the other chemicals and solvents were purchased from Aldrich (St. Louis, MO) and used as received. KB cells were from American Type Tissule Collection (ATCC, Rockville, Maryland). Penicillin, streptomycin, fetal bovine calf serum (FBS) were purchased from Sigma ( $\mathrm{St}$ Louis, MO). Trypsin-EDTA, Dulbecco's PBS, and RPMI 1640 medium (with or without FA) was obtained from GIBCO-BRL (Gaithersburg, MD). Water used in all experiments was purified using a Milli-Q Plus 185 water purification system (Millipore, Bedford, MA) with resistivity higher than $18 \mathrm{M} \Omega \mathrm{cm}$. Cellulose dialysis membranes $(\mathrm{MWCO}=10000)$ were acquired from Fisher.

Synthesis of Iron Oxide NPs: The $\mathrm{Fe}_{3} \mathrm{O}_{4} \mathrm{NPs}$ were synthesized by controlled co-precipitation of $\mathrm{Fe}^{\mathrm{II}}$ and $\mathrm{Fe}^{\mathrm{III}}$ ions according to a method described elsewhere [33]. Briefly, $25 \mathrm{~mL}$ of $1 \mathrm{M}$ $\mathrm{FeCl}_{3} \cdot 6 \mathrm{H}_{2} \mathrm{O}, 0.5 \mathrm{~m} \mathrm{FeCl}{ }_{2} \cdot 4 \mathrm{H}_{2} \mathrm{O}$ and $0.4 \mathrm{M} \mathrm{HCl}$ mixture solution was prepared in water under vigorous stirring. The co-precipitation of $\mathrm{Fe}_{3} \mathrm{O}_{4}$ NPs was carried out in a three-neck round-bottom flask. The above mixture solution was added to $250 \mathrm{~mL}$ of $0.5 \mathrm{M} \mathrm{NaOH}$, which was preheated to $80^{\circ} \mathrm{C}$ before the co-precipitation reaction. The reaction was protected under $\mathrm{N}_{2}$ atmosphere and was vigorously stirred. Black powder was collected by sedimentation with the help of an external magnetic field and washed several times with water until stable ferrofluid was obtained. Finally, the particles were redispersed in water.

Synthesis of FI- and FA-Functionalized Dendrimers: Amine-terminated $\mathrm{G} 5$ dendrimer $\left(\mathrm{G} 5 . \mathrm{NH}_{2}\right)$ was conjugated with FI or both FI and FA moieties, according to previously published reports [29,46,47]. Briefly, G5. $\mathrm{NH}_{2}(60 \mathrm{mg}, 0.00225301 \mathrm{mmol})$ was dissolved in anhydrous DMSO $(24 \mathrm{~mL})$. To the above solution was added dropwise a solution of FI $(4.4 \mathrm{mg}, 0.00563275 \mathrm{mmol})$ in DMSO $(24 \mathrm{~mL})$ under vigorous stirring at room temperature. The reaction was stopped after $24 \mathrm{~h}$. The mixture was dialyzed against PBS buffer (3 times 41 ) and water (3 times 4 1) for 3 days through a 10000 MWCO membrane. Lyophilization gave $\mathrm{G} 5 . \mathrm{NH}_{2}-\mathrm{FI}$ as an orange solid $(60.6 \mathrm{mg}$, yield $94.0 \%)$.

For the synthesis of G5.NH $\mathrm{NH}_{2}$-FI-FA, FA $(3.7 \mathrm{mg}, 0.0084004 \mathrm{mmol})$ and EDC $(9.3 \mathrm{mg}, 0.021001 \mathrm{mmol})$ were dissolved in DMSO $(3 \mathrm{~mL})$ and the mixture was stirred at room temperature for $3 \mathrm{~h}$ to activate the $\gamma$-carboxylic acid of FA. The resulting solution was added dropwise to a solution of G5.NH 2 -FI (30 mg, $0.0010501 \mathrm{mmol})$ in DMSO $(12 \mathrm{~mL})$ under vigorous stirring at room temperature. After 3 days, the reaction mixture was dialyzed through a $10000 \mathrm{MWCO}$ membrane against PBS buffer ( 3 times 41 ) and water ( 3 times 41 ) for 3 days, followed by lyophilization to give $\mathrm{G} 5 . \mathrm{NH}_{2}$-FI-FA $(31.2 \mathrm{mg}$, yield $96.4 \%$ ). The G5.NH ${ }_{2}$-FI and G5.NH - -FI-FA conjugates were characterized by ${ }^{1} \mathrm{H}$ NMR, matrix-assisted laser desorption ionization-time of flight (MALDI-TOF) mass spectrometry, and UV-vis spectrometry (Supporting Information, Figs. S1-3) [29,46]. The numbers of FI and FA moieties conjugated onto each G5 dendrimer were estimated by comparing the differences between the integration values of ${ }^{1} \mathrm{H}$ NMR signals associated with dendrimers and the FI and FA moieties. The average numbers of FI and FA moieties conjugated onto each G5 dendrimer were estimated to be 4.5 and 4.8, respectively. The molecular weights of G5. $\mathrm{NH}_{2}$-FI and G5. $\mathrm{NH}_{2}$-FI-FA conjugates were determined to be 29564 and 33484, respectively.

Fabrication of Multifunctional Dendrimer-Functionalized Iron Oxide NPs: The LbL assembly of oppositely charged PSS and dendrimers was performed according to the literature $[20,23,48,49]$. Briefly, a solution of $\mathrm{Fe}_{3} \mathrm{O}_{4} \mathrm{NPs}(5 \mathrm{mg}$ in $0.5 \mathrm{~mL}$ water) was added with $1 \mathrm{~mL}$ of a PSS solution $\left(2 \mathrm{mg} \mathrm{mL}^{-1}\right.$, containing $\left.0.5 \mathrm{M} \mathrm{NaCl}\right)$ with occasional shaking. After adsorption of PSS for $20 \mathrm{~min}$, the suspension was centrifuged at $8000 \mathrm{rpm}$ for $10 \mathrm{~min}$. The supernatant was then carefully removed, and the coated $\mathrm{Fe}_{3} \mathrm{O}_{4}$ NPs were washed by three alternate cycles of centrifuging and resuspending the particles in pure water. Then $1 \mathrm{~mL}$ of 
G5. $\mathrm{NH}_{2}$-FI-FA solution $\left(1 \mathrm{mg} \mathrm{mL}^{-1}\right.$, containing $\left.0.5 \mathrm{M} \mathrm{NaCl}\right)$ was added into the PSS-modified $\mathrm{Fe}_{3} \mathrm{O}_{4} \mathrm{NP}$ suspension and purified in the same manner. The PSS/G5. $\mathrm{NH}_{2}$-FI-FA-coated $\mathrm{Fe}_{3} \mathrm{O}_{4}$ NPs were subjected to an acetylation reaction to neutralize the remaining amine groups of G5. $\mathrm{NH}_{2}$-FI-FA dendrimers, using a procedure described elsewhere [50]. In brief, the $\mathrm{Fe}_{3} \mathrm{O}_{4} / \mathrm{PSS} / \mathrm{G} 5 . \mathrm{NH}_{2}$-FI-FA NPs (in $1 \mathrm{~mL}$ water) were added with triethylamine $(2.48 \mu \mathrm{L})$ and mixed well. Then, a methanol solution $(0.1 \mathrm{~mL})$ containing $1.82 \mathrm{mg}$ acetic anhydride was added dropwise into the $\mathrm{Fe}_{3} \mathrm{O}_{4} / \mathrm{PSS} / \mathrm{G} 5 . \mathrm{NH}_{2}$-FI-FA NP/triethylamine solution The reaction mixture was vigorously shaken for $24 \mathrm{~h}$. The formed $\mathrm{Fe}_{3} \mathrm{O}_{4} / \mathrm{PSS} / \mathrm{G} 5$.NHAc-FI-FA NPs were purified by 4 cycles of centrifugation/washing/redispersion in water. For biological testing, the NPs were transferred to PBS buffer solution by centrifugation and redispersion. The NPs were stored at $4{ }^{\circ} \mathrm{C}$ before biological testing. The control $\mathrm{Fe}_{3} \mathrm{O}_{4} / \mathrm{PSS} / \mathrm{G} 5$.NHAc-FI NPs without FA conjugation were prepared in the same manner as the procedure used to prepare $\mathrm{Fe}_{3} \mathrm{O}_{4} / \mathrm{PSS} /$ G5.NHAc-FI-FA NPs.

General Characterization Methods: ${ }^{1} \mathrm{H}$ NMR spectra of dendrimers were recorded on a Bruker DRX 500 nuclear magnetic resonance spectrometer. Samples were dissolved in $\mathrm{D}_{2} \mathrm{O}$ before NMR measurements. UV-vis spectra of dendrimers were collected using a Perkin Elmer Lambda 20 UV-vis Spectrometer. All samples were dissolved in water at the concentration of $1 \mathrm{mg} \mathrm{mL}^{-1}$. MALDI-TOF mass spectra were acquired using a Micromass TofSpec-2E spectrometer (Beverly, MA) according to a procedure described in our previous report [51]. The iron concentration of $\mathrm{Fe}_{3} \mathrm{O}_{4} \mathrm{NPs}$ before and after surface modification was determined by an atomic absorption spectrometer (AA903, ARL). A defined volume of the NPs were digested in $1.0 \mathrm{M}$ nitric acid before measurements. The surface potential of functionalized $\mathrm{Fe}_{3} \mathrm{O}_{4} \mathrm{NPs}$ was measured by a Malvern Zetasizer Nano ZS model ZEN3600 (Worcestershire, UK) equipped with a standard $633 \mathrm{~nm}$ laser. The size and morphology of $\mathrm{Fe}_{3} \mathrm{O}_{4}$ NPs were characterized by a Philips CM-100 TEM equipped with a Hamamatsu Digital Camera ORCA-HR operated using AMT software (Advanced Microscopy Techniques Corp, Danver, MA). The operation voltage was kept at $60 \mathrm{kV}$. TEM samples were prepared by deposition of a diluted particle suspension $(5 \mu \mathrm{L})$ onto a carbon-coated copper grid and air-dried before the measurement. Stained specimens were prepared by depositing the sample solutions on the grid and inverting the grid on a drop of aqueous phosphotungstic acid solution that had been neutralized with $\mathrm{NaOH}(2 \%$ mass fraction of phosphotungstic acid). The grid was then blotted on filter paper and air-dried. The size distribution histogram of $\mathrm{Fe}_{3} \mathrm{O}_{4}$ NPs was measured using ImageJ software (http://rsb.info.nih.gov/ij/download.html). For each sample, 300 nanoparticles were randomly selected to analyze the size.

KB Cell Culture: The KB cells were continuously grown in two 24-well plates, one in FA-free media and the other in regular RPMI 1640 medium supplemented with penicillin $\left(100\right.$ units $\left.\mathrm{mL}^{-1}\right)$, streptomycin $\left(100 \mu \mathrm{g} \mathrm{mL}^{-1}\right), 10 \%$ heat-inactivated FBS, and $2.5 \mu \mathrm{M}$ FA. The cells grown in FA-free media express high-level FAR, while the cells grown in FA-containing media express low-level FAR.

Determination of Cell Viability: Cell viability was measured by fluorescein diacetate (FDA) and propidium iodide (PI) staining. FDA stains live cells, while PI stains dead cells. The stained cells were quantified by flow cytometry as described by Killinger [52]. Briefly, $6 \times 10^{4}$ $\mathrm{KB}$ cells per well were seeded into a 24-well plate and incubated with $0-150 \mu \mathrm{g} \mathrm{mL}^{-1}$ of unmodified $\mathrm{Fe}_{3} \mathrm{O}_{4} \mathrm{NPs}, \mathrm{Fe}_{3} \mathrm{O}_{4} / \mathrm{PSS} / \mathrm{G} 5$.NHAc-FI NPs, and $\mathrm{Fe}_{3} \mathrm{O}_{4} / \mathrm{PSS} / \mathrm{G} 5 . N H A c-F I-F A ~ N P s$ for $24 \mathrm{~h}$ at $37^{\circ} \mathrm{C}$. Ten thousand cells were acquired from each sample for flow cytometric analysis. The morphology of cells treated with functionalized $\mathrm{Fe}_{3} \mathrm{O}_{4} \mathrm{NPs}$ with $\mathrm{Fe}$ concentrations of $0,22.5,50$, and $150 \mu \mathrm{g} \mathrm{mL}^{-1}$ were observed by a phase-contrast microscopy (Leica DMIRB fluorescent inverted microscope). The magnification is set at $200 \times$ for all samples.

Determination of Binding Affinity by Flow Cytometry: Approximately $1 \times 10^{5}$ cells per well were seeded in 24-well plates the day before the experiments. An hour before initiating an experiment, the cells were rinsed four times with serum-free and FA-deficient RPMI 1640 media. $\mathrm{Fe}_{3} \mathrm{O}_{4} /$ PSS/G5.NHAc-FI and $\mathrm{Fe}_{3} \mathrm{O}_{4} /$ PSS/G5.NHAc-FI-FA NPs were added at $\mathrm{Fe}$ concentrations of $0-90 \mu \mathrm{g} \mathrm{mL}^{-1}$. After $1 \mathrm{~h}$ incubation at $37^{\circ} \mathrm{C}, \mathrm{KB}$ cells with both high- and low-level FAR were trypsinized and suspended in PBS containing $0.1 \%$ bovine serum albumin, and then analyzed using a Coulter EPICS-XL MCL Beckman-Coulter flow cytometer. The FL1-fluorescence of 10000 cells was measured, and the mean fluorescence of gated viable cells was quantified using Expo32 software (Beckman-Coulter, Miami, FL).

Confocal Laser Scanning Microscopy: Confocal microscopic analysis was performed in cells plated on a plastic cover-slip using an Olympus FluoView 500 laser scanning confocal microscope (Melville, NY). FI fluorescence was excited with a $488 \mathrm{~nm}$ argon blue laser and emission was measured through a 505-525 barrier filter. The optical section thickness was set at $5 \mu \mathrm{m}$. The KB-HFAR cells were incubated with $\mathrm{Fe}_{3} \mathrm{O}_{4} / \mathrm{PSS} / \mathrm{G} 5$.NHAc-FI or $\mathrm{Fe}_{3} \mathrm{O}_{4} / \mathrm{PSS} / \mathrm{G} 5$.NHAc-FI-FA NPs for $2 \mathrm{~h}$ at $37^{\circ} \mathrm{C}$. Then the cells were washed with PBS. The nuclei were counterstained with $1 \mu \mathrm{g} \mathrm{mL}^{-1}$ of Hoescht33342, using a standard procedure. Samples were scanned on an Olympus IX-71 inverted microscope, using a $60 \times$ water immersion objective and magnified with FluoView software.

Transmission Electron Microscopy (TEM): The uptake of functionalized $\mathrm{Fe}_{3} \mathrm{O}_{4}$ NPs was further examined by a Phillips CM 100 TEM microscope operating at a voltage of $60 \mathrm{kV}$. Images were recorded using a Hamamatsu digital camera controlled by AMT (advance microscopy technology) software. The KB-HFAR cells were incubated with $\mathrm{Fe}_{3} \mathrm{O}_{4} /$ PSS/G5.NHAc-FI or $\mathrm{Fe}_{3} \mathrm{O}_{4} / \mathrm{PSS} / \mathrm{G} 5 . N H A c-F I-F A ~ N P s$ for $2 \mathrm{~h}$ at $37^{\circ} \mathrm{C}$. The medium was then removed and the cells were washed with Sorenson buffer and fixed at room temperature for $1 \mathrm{~h}$ using $2.5 \%$ of glutaraldehyde in Sorenson buffer. The cells were rinsed 3 times with Sorenson buffer, resuspended in the same medium, and post-fixed using $1.0 \%$ osmium tetroxide for $1 \mathrm{~h}$. After additional washing in buffer, the cells were dehydrated in a series of ethanol solutions of $30 \%, 50 \%$, $70 \%, 95 \%$, and $100 \%$. Samples were further infiltrated using the following sequence of mixtures of $100 \%$ ethanol and Epon: 3 parts of ethanol +1 part resin (for $1 \mathrm{~h}$ ), 1 part of ethanol +1 part resin (for $1 \mathrm{~h}$ ), 1 part of ethanol +3 parts resin (overnight), full-strength resin $(4 \mathrm{~h})$, and full-strength resin (overnight). After the third change of resin, polymerization was performed and sections with a thickness of $75 \mathrm{~nm}$ were obtained using a Reichart Ultramicrotom. Sections were mounted on 200 mesh copper grids before TEM measurements.

In Vitro MR Relaxometry and Imaging: $5 \times 10^{6} \mathrm{~KB}-\mathrm{HFAR}$ cells were incubated with $\mathrm{Fe}_{3} \mathrm{O}_{4} / \mathrm{PSS} / \mathrm{G} 5 . \mathrm{NHAc}-\mathrm{FI}$ and $\mathrm{Fe}_{3} \mathrm{O}_{4} / \mathrm{PSS} /$ G5.NHAc-FIFA NPs with Fe concentrations of $11.3,22.5$, and $45 \mu \mathrm{g} \mathrm{mL}^{-1}$ for $30 \mathrm{~min}$ in an ice bath. Live cells are usually cultured with a complete medium at $37^{\circ} \mathrm{C}$. For the MRI studies, live cells were trypsinized and suspended in PBS (instead of cell culture medium) and incubated with NPs. Live cells in PBS have a higher viability at $4{ }^{\circ} \mathrm{C}$ or in an ice bath than at room temperature, so we incubated cells with NPs in an ice bath. The cells were then washed with PBS buffer three times. The cells were centrifuged to prepare pellets for MR imaging. Studies were performed with a 2.0 T Varian Unity/Inova system (Palo Alto, CA) using homebuilt RF coils. One hundred microliters of PBS was added to each cell pellet, and the cells were suspended by gentle shaking. T1 and T2 of the cell suspensions were measured in each sample vial with inversion recovery and CPMG pulse sequences, respectively. The cells were then allowed to settle and a phantom was constructed consisting of all of the sample vials. A spin-echo image (TR/TE $2000 / 8 \mathrm{~ms}$ ) with a $2.0 \mathrm{~mm}-$ slice thickness and an in-plane resolution of $0.312 \mathrm{~mm}$ was acquired through the plane of the cells.

Received: November 27, 2006

Revised: January 31, 2007

Published online: August 31, 2007

[1] A. K. Gupta, M. Gupta, Biomaterials 2005, 26, 3995.

[2] C. C. Berry, A. S. G. Curtis, J. Phys. D 2003, 36, R198.

[3] S. I. Stoeva, F. Huo, J.-S. Lee, C. A. Mirkin, J. Am. Chem. Soc. 2005 , 127,15362

[4] I. J. M. de Vries, W. J. Lesterhuis, J. O. Barentsz, P. Verdijk, J. H. van Krieken, O. C. Boerman, W. J. G. Oyen, J. J. Bonenkamp, J. B. Boezeman, G. J. Adema, J. W. M. Bulte, T. W. J. Scheenen, C. J. A. Punt, A. Heerschap, C. G. Figdor, Nat. Biotechnol. 2005, 23, 1407. 
[5] J. W. M. Bulte, T. Douglas, B. Witwer, S. C. Zhang, E. Strable, B. K Lewis, H. Zywicke, B. Miller, P. van Gelderen, B. M. Moskowitz, L. D. Duncan, J. A. Frank, Nat. Biotechnol. 2001, 19, 1141.

[6] S. Mornet, S. Vasseur, F. Grasset, E. Duguet, J. Mater. Chem. 2004, 14, 2161.

[7] A. Moore, L. Josephson, R. M. Bhorade, J. P. Basilion, R. Weissleder, Radiology 2001, 221, 244.

[8] C. C. Berry, S. Charles, S. Wells, M. J. Dalby, A. S. G. Curtis, Int. J. Pharm. 2004, 269, 211.

[9] A. Moore, J. Basilion, E. A. Chiocca, R. Weissleder, Biochim. Biophys. Acta 1998, 1402, 239.

[10] Z. M. Qian, H. Li, H. Sun, K. Ho, Pharmacol. Rev. 2002, 54, 561

[11] Y.-W. Jun, Y.-M. Huh, J.-S. Choi, J.-H. Lee, H.-T. Song, S.-J. Kim, S. Yoon, K.-S. Kim, J.-S. Shin, J.-S. Suh, J. Cheon, J. Am. Chem. Soc. 2005, 127, 5732.

[12] Y.-M. Huh, Y.-W. Jun, H.-T. Song, S. Kim, J.-S. Choi, J.-H. Lee, S. Yoon, K.-S. Kim, J.-S. Shin, J.-S. Suh, J. Cheon, J. Am. Chem. Soc. 2005, 127, 12387.

[13] O. Veiseh, C. Sun, J. Gunn, N. Kohler, P. Gabikian, D. Lee, N. Bhattarai, R. Ellenbogen, R. Sze, A. Hallahan, J. Olson, M. Zhang, Nano Lett. 2005, 5, 1003.

[14] Y. Zhang, N. Kohler, M. Zhang, Biomaterials 2002, 23, 1553.

[15] N. Kohler, G. E. Fryxell, M. Zhang, J. Am. Chem. Soc. 2004, 126, 7206.

[16] F. Sonvico, S. Mornet, S. Vasseur, C. Dubernet, D. Jaillard, J. Degrouard, J. Hoebeke, E. Duguet, P. Colombo, P. Couvreur, Bioconjugate Chem. 2005, 16, 1181 .

[17] G. Decher, Science 1997, 277, 1232.

[18] F. Caruso, R. A. Caruso, H. Mohwald, Science 1998, 282, 1111.

[19] S. Hou, J. Wang, C. R. Martin, Nano Lett. 2005, 5, 231.

[20] G. Schneider, G. Decher, Nano Lett. 2004, 4, 1833.

[21] G. Schneider, G. Decher, N. Nerambourg, R. Praho, M. H. V. Werts, M. Blanchard-Desce, Nano Lett. 2006, 6, 530.

[22] D. I. Gittins, F. Caruso, Adv. Mater. 2000, 12, 1947.

[23] D. I. Gittins, F. Caruso, J. Phys. Chem. B 2001, 105, 6846.

[24] A. F. Thunemann, D. Schutt, L. Kaufner, U. Pison, H. Mohwald, Langmuir 2006, 22, 2351.

[25] D. Wang, A. L. Rogach, F. Caruso, Nano Lett. 2002, 2, 857.

[26] N. Kato, F. Caruso, J. Phys. Chem. B 2005, 109, 19604.

[27] C. Cortez, E. Tomaskovic-Crook, A. P. R. Johnston, B. Radt, S. H. Cody, A. M. Scott, E. C. Nice, J. K. Heath, F. Caruso, Adv. Mater. 2006, 18, 1998.

[28] J. F. Kukowska-Latallo, K. A. Candido, Z. Cao, S. S. Nigavekar, I. J. Majoros, T. P. Thomas, L. P. Balogh, M. K. Khan, J. R. Baker, Jr., Cancer Res. 2005, 65, 5317.
[29] I. J. Majoros, T. P. Thomas, C. B. Mehta, J. R. Baker, Jr., J. Med. Chem. 2005, 48, 5892.

[30] T. P. Thomas, I. J. Majoros, A. Kotlyar, J. F. Kukowska-Latallo, A. Bielinska, A. Myc, J. R. Baker, Jr., J. Med. Chem. 2005, 48, 3729.

[31] I. J. Majoros, A. Myc, T. Thomas, C. B. Mehta, J. R. Baker, Jr., Biomacromolecules 2006, 7, 572.

[32] E. C. Wiener, S. Konda, A. Shadron, M. Brechbiel, O. Gansow, Invest. Radiol. 1997, 32, 748.

[33] M. Mikhaylova, D. K. Kim, C. C. Berry, A. Zagorodni, M. Toprak, A. S. G. Curtis, M. Muhammed, Chem. Mater. 2004, 16, 2344

[34] B. L. Frankamp, A. K. Boal, M. T. Tuominen, V. M. Rotello, J. Am Chem. Soc. 2005, 127, 9731.

[35] E. Strable, J. W. M. Bulte, B. Moskowitz, K. Vivekanandan, M. Allen, T. Douglas, Chem. Mater. 2001, 13, 2201.

[36] D. Weitman, R. H. Lark, L. R. Coney, D. W. Fort, V. Frasca, V. R. Surawski, B. A. Kamen, Cancer Res. 1992, 52, 3396.

[37] I. G. Campbell, T. A. Jones, W. D. Foulkes, J. Trowsdale, Cancer Res. 1991, 51,5329 .

[38] J. F. Ross, P. K. Chaudhuri, M. Ratnam, Cancer 1994, 73, 2432.

[39] L. Quinti, R. Weissleder, C.-H. Tung, Nano Lett. 2006, 6, 488.

[40] M. Zhao, M. F. Kircher, L. Josephson, R. Weissleder, Bioconjugate Chem. 2002, 13, 840 .

[41] A. W. Bosman, H. M. Janssen, E. W. Meijer, Chem. Rev. 1999, 99 , 1665 .

[42] T. Imae, K. Funayama, K. Aoi, K. Tsutsumiuchi, M. Okada, M. Furusaka, Langmuir 1999, 15, 4076.

[43] F. Caruso, H. Lichtenfeld, E. Donath, H. Mohwald, Macromolecules 1999, 32, 2317.

[44] D. A. Tomalia, A. M. Naylor, W. A. Goddard, III, Angew. Chem. Int. Ed. Engl. 1990, 29, 138.

[45] Y. Choi, T. Thomas, A. Kotlyar, M. T. Islam, J. R. Baker, Jr., Chem. Biol. 2005, 12, 35 .

[46] X. Shi, I. Majoros, A. K. Patri, X. Bi, M. T. Islam, A. Desai, T. R. Ganser, J. R. Baker, Jr., Analyst 2006, 131, 374.

[47] A. Quintana, E. Raczka, L. Piehler, I. Lee, A. Myc, I. Majoros, A. K. Patri, T. Thomas, J. Mule, J. R. Baker, Jr., Pharm. Res. 2002, 19, 1310.

[48] A. J. Khopade, F. Caruso, Nano Lett. 2002, 2, 415.

[49] A. J. Khopade, F. Caruso, Biomacromolecules 2002, 3, 1154.

[50] I. J. Majoros, B. Keszler, S. Woehler, T. Bull, J. R. Baker, Jr., Macromolecules 2003, 36, 5526.

[51] X. Shi, I. Bányai, K. Rodriguez, M. T. Islam, W. Lesniak, P. Balogh, L. Balogh, J. R. Baker, Jr., Electrophoresis 2006, 27, 1758.

[52] W. A. Killinger, Jr., D. B. Dorofi, E. A. Tinsley, Jr., B. A. Keagy, G. Johnson, Jr., Ann. Thorac. Surg. 1992, 53, 472. 